\title{
An Unusual Presentation of Multiple Myeloma: Plasmacytic Ascites Complicated by Duodenal Involvement Multiple Myeloma'nın Nadir bir Prezentasyonu: Duedonal Tutulum ile Komplike olan Plazmasitik Asit
}

\author{
${ }^{1}$ Güven Barış Cansu, ${ }^{2}$ Hava Üsküdar Teke, ${ }^{2}$ Olga Meltem Akay, ${ }^{3}$ Emre Entok \\ ${ }^{1}$ Eskişehir Yunusemre State Hospital, Endocrinology and Metabolism, Eskişehir, Turkey \\ ${ }^{2}$ Eskişehir Osmangazi University Medical School, Hematology Division, Eskişehir, Turkey \\ ${ }^{3}$ Eskişehir Osmangazi University Medical School, Pathology Division, Eskişehir, Turkey
}

\begin{abstract}
The incidence of gastrointestinal system involvement during the course of multiple myeloma $(\mathrm{MM})$ is rare. The usually affected sites of GI tract are small and large bowel, stomach, and rarely esophagus. Only a few MM cases are also known with myelomatous ascites at presentation. In this report, we present a 67-year old patient who developed myelomatosus ascites. Although rare, MM can involve extramedullary areas such as duodenum and different kinds of complications may occur. In addition to standard diagnostic and treatment methods, individualized diagnostic and therapeutic options should be considered for such patients.
\end{abstract}

Key words: multiple myeloma, ascites, duodenal involvement

Cansu G. B., Üsküdar T. H., Akay O. M., Entok E (2017). An Unusual Presentation of Multiple Myeloma: Plasmacytic Ascites Complicated by Duodenal Involvement. Osmangazi Journal of Medicine, 392(): 60-64. DOI: 10.20515/otd.308424.

Öz: Multiple myeloma (MM) seyrinde gastrointestinal sistem tutulumu nadirdir. Gastrointestinal sistemde sıklıkla ince ve kalın bağırsak, mide ve nadiren de özefagus tutulur. MM vakalarında myeloma bağlı asit ile başvuran hasta sayısı çok azdır. Bu vaka sunumunda myeloma bağlı asit gelişen 67 yaşında bir erkek hasta sunulmuştur. Nadir görülmesine rağmen MM duodenum gibi extramedüller bölgeleri tutabilir ve buna bağlı farklı komplikasyonlar gelişebilir. Bu tür hastalarda standart tanı ve tedavi yöntemlerine ek olarak, bireyselleştirilmiş tanı ve tedavi seçenekleri de düşünülmelidir. Anahtar Kelimeler: multiple myelom, asit, duodenal tutulum

Cansu G. B., Üsküdar T. H., Akay O. M., Entok E (2017). Multiple Myeloma'nın nadir bir prezentasyonu: Duedonal tutulum ile komplike olan plazmasitik asit, Osmangazi Tip Dergisi 39(2): 60-64. DOI: 10.20515/otd.308424. 


\section{Introduction}

Plasma cell neoplasms are classically categorized into four groups; multiple myeloma (MM), plasma cell leukemias, solitary plasmacytomas of the bone (SPB), and extramedullary plasmacytomas (EMP) (1). Plasmacytomas are extramedullary accumulations of plasma cells and can occur nearly in $20 \%$ of MM patients (1). The incidence of gastrointestinal (GI) involvement during the course of MM is approximately $10-13 \%$ (2). The usually affected sites of GI tract are small and large bowel, stomach, and rarely esophagus (3). Only a few MM cases are also known with myelomatous ascites at presentation (4).

Here in, we present an unusual presentation of MM with plasmacytic ascites complicated by duodenal involvement.

\section{Case Report}

A male of sixty-seven old presented with a 2month history of abdominal distention, fatigue, and low back and leg pain. On physical examination conjunctivas were pale, skin and sclera were ichteric and moderate ascites was found. His complete blood count revealed hemoglobin $11 \mathrm{~g} / \mathrm{dl}$, hematocrit $32 \%$, white blood cell counts 5900/UL with normal differential; and platelets 156.000/UL. Erythrocyte sedimentation rate was 123 $\mathrm{mm} /$ hour. Blood chemistries showed an elevated LDH of $712 \mathrm{U} / \mathrm{L}$ (normal range, 240480), an ALP of $904 \mathrm{U} / \mathrm{L}$ (98-270), GGT of $494 \mathrm{U} / \mathrm{L}(8-50)$, total bilirubin of $9.59 \mathrm{mg} / \mathrm{dl}$ (0.1-0.9), and direct bilirubin of $6.7 \mathrm{mg} / \mathrm{dl}$. Total proteins were $9.18 \mathrm{~g} / \mathrm{dl}$ (6-8.5) with albumin $4.13 \mathrm{~g} / \mathrm{dl}$ (3.5-5.0) and calcium of $10.4 \mathrm{mg} / \mathrm{dl}$ (8.5-10.5). Beta-2 microglobulin was $5.47(1.42-3.21)$ in the serum. AST and ALT were elevated at $246 \mathrm{U} / \mathrm{L}$ (7-39) and 259 U/L (2-40), respectively. Renal function and serum electrolytes were within normal limits. Serum protein electrophoresis disclosed monoclonal gammopathy with an elevated IgA of $3390 \mathrm{mg} / \mathrm{dl}$ (82-453), and a low IgG of $409 \mathrm{mg} / \mathrm{dl}$ (751-1560), and an IgM of $7.55 \mathrm{mg} / \mathrm{dl}$ (46-304) while free kappa light chain was detected. Plain film skeletal survey revealed multiple osteolytic lesions of the lumbar spine, pelvis, clavicula and skull. Paracentesis demonstrated clear ascites fluid with a level of $2.54 \mathrm{~g} / \mathrm{dl}$ protein, $0.91 \mathrm{~g} / \mathrm{dl}$ of albumin and $9.88 \mathrm{mg} / \mathrm{dl}$ of beta- 2 microglobulin. Ascitic fluid electrophoresis also demonstrated a monoclonal gammopathy. By flow cytometric analysis, CD38/138 ratio was found as $65 \%$ on bone marrow aspiration sample and $14 \%$ in ascites fluid. Plasma cells were shown in peripheral smear of ascites fluid (Figure 1A). Since the patient developed hematemesis, an upper gastrointestinal system endoscopy was performed on which a giant ulcer was detected in the second portion of the duodenum. The biopsy of the ulcer showed marked monoclonal plasma-cell infiltration by immunohistochemistry and immunoperoxidase stain for CD138 showed diffuse and strong positivity (Figure 1B). A F18 fluorodeoxyglucose (FDG) whole body Positron Emission Tomography (PET) in combination with computed tomography (CT) scan was performed and revealed an increased F18 FDG accumulation in anterior portion of left inferior quadrant abdomen which was matched to colon trace, in the localization of pancreas in the left inguinal area, in the anterior portion of thoracal vertebrae and in the soft tissue localization of the anterior sacrum. Additionally, thorax images revealed a focal activity which was matched with lymphadenopathy in the left lateral of the middle mediastine (Figure 2). According to these findings, the patient was diagnosed as Ig type A MM with plasmacytic ascites and duodenal involvement and VCMP (vincristine, cyclophosphamide, melphalan, prednisolone) chemotherapy protocol was begun. Upper gastrointestinal bleeding was treated conservatively with proton pump inhibitors. Although his ascites and ichter disappeared after two courses of VCMP, there was no resolution of the abdominal lesion in PET/CT. Bortezomib therapy was recommended and the patient agreed to receive this agent. After one course of bortezomib, he again developed upper gastrointestinal bleeding and was managed with proton pump inhibitors. Since then, the patient and his family refused further cytotoxic treatment and instead chose to receive supportive therapy. Then, patient has not come to routine follow-up and couldn't get contact from the family. 


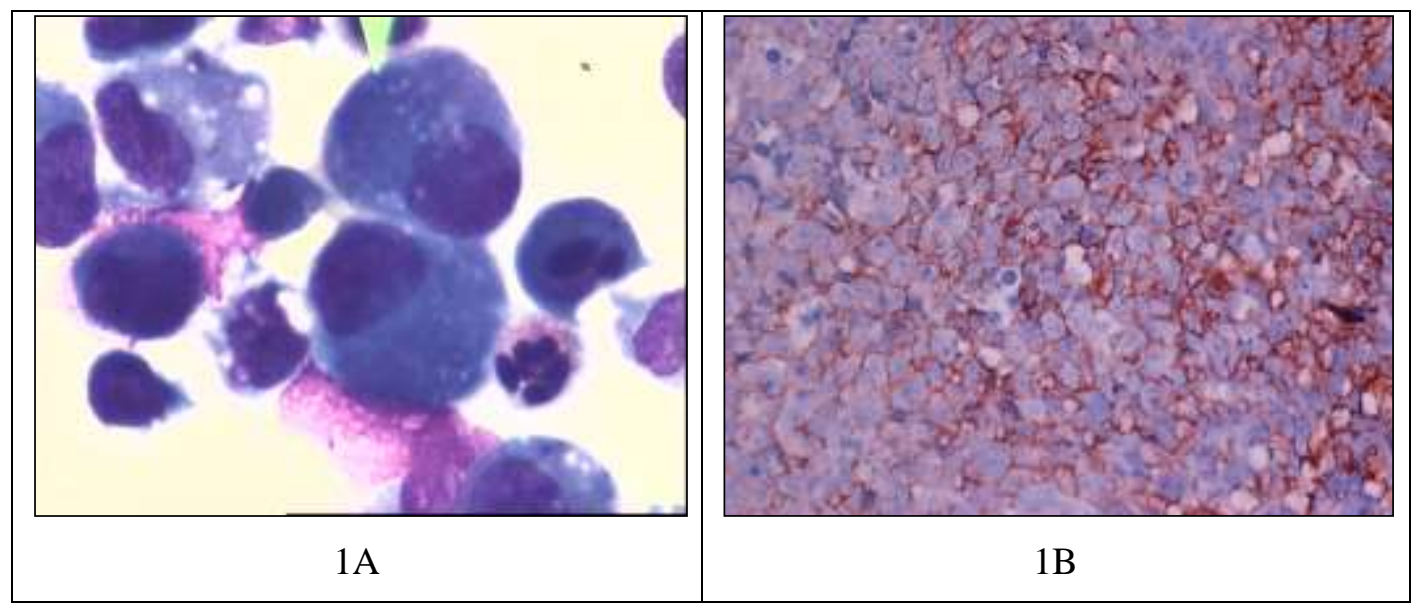

Figure 1: 1A. Representative plasma cells present in the ascitic fluid (Wright's stain) (X100). $1 B$. Immunoperoxidase stain for CD138 shows diffuse and strong positivity in neoplastic plasma cells in the biopsy of the duodenal ulcer $(x 200)$

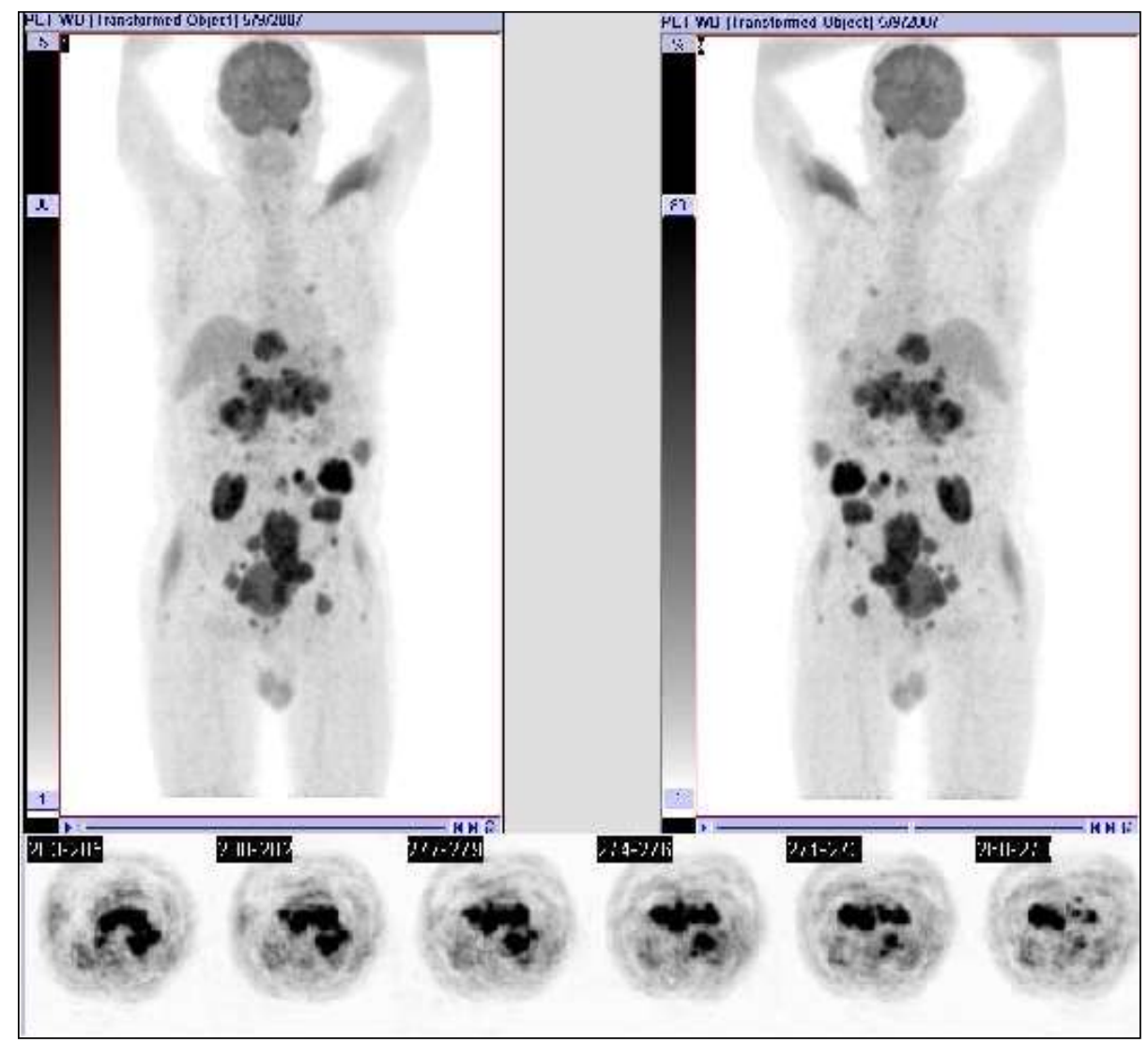

Figure 2. Heterogen, irregular restricted, hypermetabolic images obtained at ductus choledochus, duodenum and pancreas regions with transaxial and whole body F-18 FDG PET.

\section{Discussion}

Our patient is one of few MM cases in the literature with significant bleeding from a duodenal plasmacytoma and ascites (3). The presentation with ascites of $\mathrm{MM}$ is also a rare condition. In the literature research and case report of Greer et al (5) there was not any case presenting with ascites. In 1987 Karp and Shareff have reported that especially Ig type G MM could be presented with ascites (6). Ascites formation in a myeloma patient is 
usually associated with extensive liver infiltration with plasma cells causing portal hypertension, but may be secondary to infectious peritonitis, or very rarely, to myelomatous peritoneal infiltration. Systemic amyloidosis, tuberculous peritonitis, hemangioendothelial sarcoma, plasma cell sarcoma, and spontaneous splenic ruptures are the other possible etiologies of ascites in MM patients (7). The low serum ascit-albumin gradient (SAAG) without the myelomatous infiltration of the liver and the presence of the malignant plasma cells in the ascitic fluid supports myelomatous peritoneal involvement (7). Also the high serum and ascitic level of beta-2 microglobulin could be attributed to its cytokine-mediated hyperproduction by tumor cells or by activated infiltrated cells (8). Although SAAG was 3.22 in our case, increased levels of beta 2 microglobulin was detected both in the serum and the ascites.

Aggressive myelomas rarely invade organs outside the bone marrow, lymphatics or reticuloendothelial system. Also diffuse intraabdominal seeding caused by myelomatous ascites or biliary obstruction is extremely rare (9). When myeloma cells spread to the intraabdominal cavity reticuloendothelial system and kidneys are the most common involved parts. In autopsy studies, over twothirds of myeloma cases were associated with microscopic infiltration of these organs (10, 11). If myeloma affects the liver, diffuse infiltration leading to intrahepatic cholestasis and jaundice is typically seen. Extrahepatic biliary obstruction caused by a hilar plasmacytoma, as in this case, is uncommon, with limited reports noted in the English literature (9). In our case, there was an obstructive ichter which could not be shown by imaging methods and necessitated an extrahepatic bilier drainage.

Plasma cell tumors rarely invade the gastrointestinal tract. In a review of 36 patients with gastrointestinal plasmacytomas, the stomach was most frequently involved, followed by the jejunum, ileum, colon, rectum, and rarely the duodenum (2). Gastrointestinal tract involvement incidence during the course of MM is approximately $10-13 \%$ (2), whereas solitary extramedullary plasmacytoma of the GI tract is noted in only $3-7 \%$ of patients with EMP (12).
In our case the endoscopic imaging and pathological examination of duodenal ulcer biopsy revealed duodenal involvement. A review of the English-language literature in 1999 revealed only 19 cases of significant hemorrhage complicating multiple myeloma or solitary EMP of the GI tract. Only two of these have experienced overt hemorrhage due to duodenal plasmacytoma (3). To the best of our knowledge, ours is the third reported case of significant bleeding from a duodenal plasmacytoma. The standard therapy approaches for GIS plasmocytomas are radiotherapy and chemotherapy. A surgical procedure may be necessary for acute bleedings while there are also case reports offering angiographic embolization to control massive bleeding (3). In our case bleeding was treated successfully by conservative methods.

The differential diagnosis of gastrointestinal blood loss in a patient with multiple myeloma should include poorly differentiated neoplasms, mucosa-associated lymphoid tissue (MALT) lymphoma and amyloidosis, as well as ulcer related and unrelated gastrointestinal bleeding disorders, such as peptic ulcer disease, arteriovenous malformation, polyps, or carcinoma. The endoscopic appearance of the gastrointestinal plasmacytoma resembles poorly differentiated neoplasms, MALT lymphoma and amyloidosis. As the management of these clinical settings differs, it is very important to have the right diagnosis (13-15). Flow cytometric analysis and histochemical examination may help in the differential diagnosis (16). In our case, there was a giant ulcer in duodenum in which CD38/138 positive cells were shown by immunohistochemical examination. For us, the differential diagnosis of gastrointestinal bleeding in $\mathrm{MM}$ is important since failure to recognize myelomatous involvement of gastrointestinal tract may result in achieving inappropriate treatment modalities of surgery, radiotherapy and/or chemotherapy.

\section{Conclusion}

Aggressive MM can involve extramedullary areas and different kinds of complications may occur. We suggest that individualized diagnostic and therapeutic options should be considered for such patients. 



\section{KAYNAKLAR}

1. Alexiou C, Reinhardt JK, Dietzfelbinger H, et al. Extramedullary plasmacytoma: tumor occurrence andtherap eutic concepts. Cancer 1999;85:2305-14.

2. Goldstein WB, Parker N. Multiple myeloma involving the GI tract. Gastroenterology 1966;51:87-93.

3. Siddique I, Papadakis KA, Weber DM, Glober G. Recurrent bleeding from a duodenal plasmacytoma treated successfully with embolization of the gastroduodenal artery. Am J Gastroenterol. 1999 Jun;94(6):1691-2.

4. Alegre A, Martinez-Chamorro C, FernandezRanada JM. Massive myelomatous ascites responsive to $\mathrm{VAD}$ chemotherapy and autologous stem cell transplantation. Bone Marrow Transplant. 1999 Aug;24(3):343-4.

5. Greer JP, Pinson RD, Russell WG et al. Malignant plasmacytic ascites. A report of two cases and review of the literature. Cancer 1985; 56: 20012004.

6. Karp SJ, Shareef D. Ascites as a presenting feature multiple myeloma. J R Soc Med 1987;80:182-4.

7. Inoue $\mathrm{Y}$, Chua $\mathrm{K}$, McClure RF, Jimenez MC, Gocke CD, Badros AZ, Takebe N. Multiple myeloma presenting initially as a solitary pleural effusion later complicated by malignant plasmacytic ascites. Leuk Res. 2005 Jun;29(6):7158.

8. Keren D, Schliamser L, Atias D: Myeloma ascites-A favorable outcome with cyclophosphamide therapy. Am J Hematol 60:140142, 1999.

9. Attwell A, Dee E, Russ P, Nash R, Shah R. Multiple myeloma involving the porta hepatis and peritoneum causing biliary obstruction and malignant ascites. Dig Dis Sci. 2005 Jun;50(6):1068-71

10. Hayes D, BennettW: Extramedullary lesions in multiple myeloma: review of literature and pathologic studies. Arch Pathol Lab Med 53:317329,1952

11. Pasmantier MW, Azar HA: Extraskeletal spread in multiple plasma cell myeloma: a review of 57 autopsied cases. Cancer 23:167-174, 1969

12. Ingegno AP. Plasmacytoma of the gastrointestinal tract: Report of a case involving the jejunum and review of the literature. Gastroenterology 1954;26:89-102.

13. Kodama $\mathrm{Y}$ et al. (1999) MALT lymphoma simulating an extramedullary plasmacytoma of the stomach. Am J Med 107: 530-532

14. Tada $S$ et al. (1990) Endoscopic and biopsy findings of the upper digestive tract in patients with amyloidosis. Gastrointest Endosc 36: 10-14

15. Hainsworth JD et al. (1991) Poorly differentiated carcinoma of unknown primary site: clinical usefulness of immunoperoxidase staining. J Clin Oncol 9:1931-1938

16. Esfandyari $\mathrm{T}$, Abraham SC, Arora AS. Gastrointestinal plasmacytoma that caused anemia in a patient with multiple myeloma. Nat Clin Pract Gastroenterol Hepatol. 2007 Feb;4(2):111-5. 